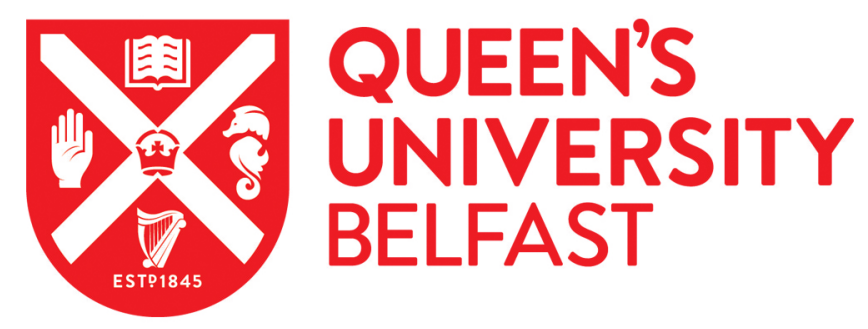

\title{
Hierarchical structuring of genetic variation at differing geographic scales in the cultivated sugar kelp Saccharina latissima
}

Mooney, K. M., Beatty, G. E., Elsäßer, B., Follis, E. S., Kregting, L., O'Connor, N. E., Riddell, G. E., \& Provan, J. (2018). Hierarchical structuring of genetic variation at differing geographic scales in the cultivated sugar kelp Saccharina latissima. Marine environmental research. https://doi.org/10.1016/j.marenvres.2018.09.029

Published in:

Marine environmental research

Document Version:

Peer reviewed version

Queen's University Belfast - Research Portal:

Link to publication record in Queen's University Belfast Research Portal

Publisher rights

Copyright 2018 Elsevier.

This manuscript is distributed under a Creative Commons Attribution-NonCommercial-NoDerivs License

(https://creativecommons.org/licenses/by-nc-nd/4.0/), which permits distribution and reproduction for non-commercial purposes, provided the author and source are cited.

\section{General rights}

Copyright for the publications made accessible via the Queen's University Belfast Research Portal is retained by the author(s) and / or other copyright owners and it is a condition of accessing these publications that users recognise and abide by the legal requirements associated with these rights.

Take down policy

The Research Portal is Queen's institutional repository that provides access to Queen's research output. Every effort has been made to ensure that content in the Research Portal does not infringe any person's rights, or applicable UK laws. If you discover content in the Research Portal that you believe breaches copyright or violates any law, please contact openaccess@qub.ac.uk. 


\section{Hierarchical structuring of genetic variation at differing geographic}

\section{scales in the cultivated sugar kelp Saccharina latissima}

Karen M. Mooney ${ }^{\mathrm{a}}$, Gemma E. Beatty ${ }^{\mathrm{b}}$, Björn Elsäßer ${ }^{\mathrm{c}}$, Emily S. Follis $^{\mathrm{a}}$, Louise Kregting ${ }^{\mathrm{d}}$,

Nessa E. O'Connor ${ }^{\mathrm{e}}$, Gillian E. Riddell ${ }^{\mathrm{a}}$, Jim Provan ${ }^{\mathrm{b} *}$

a School of Biological Sciences, Queen's University Belfast, Belfast BT9 7BL, UK

${ }^{\mathrm{b}}$ Institute of Biological, Environmental and Rural Sciences, Aberystwyth University, Aberystwyth SY23 3DA, UK

c DHI Water \& Environment, Agern Allé 5, DK-2970 Hørsholm, Denmark

${ }^{\mathrm{d}}$ School of Natural and Built Environment, Queen's University Belfast, Belfast BT9 5AG, UK

e School of Natural Sciences, Trinity College Dublin, The University of Dublin, Dublin 2, Ireland

* Corresponding Author: J.Provan@aber.ac.uk 


\section{$1 \quad$ ABSTRACT}

2

3 The cultivation of macroalgae for biofuels, food and fertilisers has increased dramatically in

4 recent years. The demand for such algal-derived products means that large scale cultivation

5 in coastal waters will become necessary to provide sufficient algal biomass. As part of the

6 process of establishing new macroalgal farms, the potential for gene flow between cultivated

7 specimens and natural populations needs to be taken into consideration. Consequently, in the

8 present study we have used a combined population genetic and hydrodynamic modelling

9 approach to determine potential levels and patterns of gene flow in the kelp Saccharina

10 latissima. Microsatellite analysis of 14 populations sampled across the northern part of the

11 Irish Sea indicated four distinct genetic clusters. These were consistent with dispersal

12 patterns indicated by the particle tracking model and show a combination of isolation by

13 distance and genetic structuring due to local hydrodynamic conditions. At smaller scales

14 (less than a few 10 s of $\mathrm{km}$ ), gene flow appears to be fairly extensive, with evidence of local

15 population connectivity due to local currents. At larger scales, however, factors such as

16 freshwater efflux and open water would appear to represent barriers to gene flow. Together,

17 these patterns suggest that factors other than simple geographical distance and proximity need

18 to be taken into account when planning the siting of kelp farms with the aim of minimizing

19 gene flow to and from natural populations.

20

21 Keywords

22 Algae, Cultivation, Dispersal, Gene flow, Hydrodynamic modelling, Kelp, Population

23 genetics, Saccharina latissima

Page $\mid 2$ 


\section{1. Introduction}

3 The popularity of macroalgal cultivation is increasing in North Western Europe owing to its 4 applicability for biofuel, food supplements and fertiliser (Wei et al., 2013). It is estimated 5 that 2,000 - 3,000 dry tonnes (equivalent to $25,000-40,000$ tonnes wet weight) of

6 macroalgae is harvested from the wild per year in the United Kingdom to produce food and

7 feed products as well as speciality chemicals and fertilisers (Schlarb-Ridley and Parker,

8 2013), but these figures lag far behind those from Southeast Asia, where over 20 million

9 tonnes were produced in 2014 (FAO, 2016; Buschmann et al., 2017). The potential

10 exploitation of macroalgae in a range of industries means that demand will increase

11 significantly and in order to provide sufficient macroalgal biomass on the potential scale required for economically viable industries, large scale cultivation in coastal waters is required (Schlarb-Ridley and Parker, 2013; Radulovich et al., 2015; Lehahn et al., 2016; Buschmann et al., 2017). Europe's extensive coastline comprises huge potential to contribute significantly to the supply of macroalgal biomass primarily due to the wide availability of numerous coastal sites to cultivate macroalgae.

Site suitability for algal cultivation can be influenced by several factors e.g. available area, photosynthetically active radiation (PAR), nutrient load, salinity and water motion (Kerrison et al., 2015; Wood et al., 2017; van der Molen et al., 2018). A further key issue in selecting sites for macroalgal farms at sea is the potential for genetic interaction of cultivated specimens on longline systems with wild populations via gamete or spore dispersal (Stévant et al., 2017). Understanding the distance over which gene flow can occur is thus vital to understand the potential for macroalgal cultivation to impact adjacent ecosystems (Coleman et al., 2009; Luttikhuizen et al., 2018). Propagule gametes and spores have a planktonic phase with the ability to swim and actively seek out optimal settlement substrata (Fredriksen 
1 et al., 1995), and photosynthesis can extend their viability in the water columns and thus their

2 dispersal potential (Reed et al., 1992). In addition, spores may survive in the water column

3 for longer periods of time following periods of dormancy (Schiel and Foster, 2006), and

4 while there is little evidence to suggest this occurs in the field, it is a condition which is

5 exploited in cultivation hatcheries (Edwards and Dring, 2011).

6 Although settlement behaviour and biological traits such as buoyancy and sinking rates

7 play a role in dispersal at the microscale $(\mathrm{cm}-\mathrm{mm})$ near the substrate (Stevens et al. 2008),

8 water motion - predominantly currents - and where in the water column the spore is (near the

9 surface or near the substrate) strongly regulates transport and dispersal of propagules with

10 limited inherent mobility, and will influence macroalgal gene flow (Norton, 1992; Gaylord et

11 al., 2002). While historically it was thought that gene flow in macroalgae was very limited

12 by geographical distance (Billot et al., 2003), more recent studies suggest that effective

13 dispersal of gametes may extend to up to several kilometres (Couceiro et al., 2013, Brennan

14 et al., 2014) and even up to 200km for Laminaria hyperborea (Fredriksen et al., 1995). This

15 is perhaps unsurprising considering that many coastal regions experience current velocities >

$16 \quad 0.5 \mathrm{~m} \mathrm{~s}^{-1}$ suggesting that currents play a significant role in the transport of propagules.

17 Although small-scale macroalgal cultivation takes place in sheltered areas e.g. in the United

18 Kingdom (Strangford Lough in Northern Ireland and Oban in Scotland), Pleubian in Brittany,

19 France and Ventry Harbour in Co. Kerry, Ireland, the implications of potentially extensive

20 large-scale cultivation developed in coastal regions are still unknown. Interest in cultivation

21 is growing with farms now being developed in the USA and Canada (Breton et al., 2018).

22 Annual harvesting of farmed strains will mean that cultivated adult populations will be

23 transient, but even so, harvesting is unlikely to be $100 \%$ efficient, and some cultivated

24 material can also become fertile early in the season (Parke, 1948), so that off-shore 
1 macroalgal farms may lead to potential genetic mixing of cultivated and indigenous

2 populations.

3 One target species for European cultivation is the sugar kelp, Saccharina latissima

4 (previously Laminaria saccharina). The genus Saccharina is widely distributed across both

5 the Northern and Southern Hemispheres (Bolton, 2010), with Bartsch et al. (2008)

6 highlighting it as a major Pacific-Atlantic species complex, while S. latissima is widespread

7 in the North Atlantic (Luttikhuizen et al., 2018), reaching as far north as the Arctic and as far

8 south as Portugal and New York (Lee and Brinkhuis, 1986; Smale et al., 2013; Guzinski et

9 al., 2016). Like all kelps, S. latissima has a biphasic life history, with an alternation of

10 generations (Dayton, 1985; Schiel and Foster, 2006). Fertilisation generally tends to happen

11 over short distances (Dayton, 1985). The reproductive success of kelp thus depends on

12 availability of female gametes and their proximity to male gametes.

13 Given the importance of understanding both local and regional patterns of gene flow to the

14 conservation and conscientious management of commercial areas, the aim of the present

15 study was to identify the factors that determine patterns of genetic variation of S. latissima

16 populations in the Irish Sea. We used a combination of microsatellite genotyping and

17 hydrodynamic modelling to test the connectivity of wild populations, thus, providing

18 valuable information on the optimal locations of future coastal kelp cultivation farms and the

19 sourcing of wild material suitable for cultivation. 


\section{2. Materials and methods}

\subsection{Sampling and DNA extraction}

To characterise native wild populations of S. latissima, individual samples were taken from

5 sites chosen to be representative of conditions across the Irish and Inner Seas off the West

6 Coast of Scotland. Each site was separated by distances $>10 \mathrm{~km}$ to test whether (and how)

7 hydrodynamic conditions determine connectivity and how far these algal spores travel to

8 understand potential genetic interaction of cultivated kelp on natural populations. Nearshore

9 cultivation takes place in Strangford Lough (Queen's University Belfast [QUB] experimental

10 site) and, consequently, samples were taken from inside the lough, as well as from around the

11 Northern Ireland coastline, the Isle of Man, and the west coast of Scotland (Fig. 1). In total,

1214 sites were sampled (eleven from Northern Ireland, two from Scotland and one from the

13 Isle of Man, Table 1, Fig. 1). At each site, thirty mature (>1m) S. latissima sporophytes were

14 randomly selected from discrete populations and a small disc $0.7 \mathrm{~cm}$ in diameter was hole-

15 punched approximately $4 \mathrm{~cm}$ from the stipe/laminar junction in an area free of epiphytes and

16 stored in powdered silica gel. DNA was extracted using the CTAB method (Doyle and

17 Doyle 1987).

\subsection{Microsatellite genotyping}

20 Five species-specific microsatellite loci were developed using a modified version of the

21 biotin / streptavidin capture method originally outlined by Kijas et al. (1994). Primer

22 sequences are given in Table 2. A further locus (Zspj39) originally developed for S. japonica

23 (Zhang et al. 2014) was also used. Loci Zspj8 and Zspj40 from the same study were tested,

24 but could not be consistently amplified and so were not used. PCR was carried out in a total

25 volume of $10 \mu \mathrm{l}$ containing $100 \mathrm{ng}$ genomic DNA, 5 pmol of 6-FAM-, ROX- or HEX- 
1 labelled M13 primer, 0.5 pmol of M13-tailed forward primer, 5 pmol reverse primer, 1x PCR

2 reaction buffer, $200 \mu \mathrm{M}$ each dNTP, $2.5 \mathrm{mM} \mathrm{MgCl}_{2}$ and $0.25 \mathrm{U}$ GoTaq Flexi DNA

3 polymerase (Promega, Sunnyvale, CA, USA). PCR was carried out on a MWG Primus

4 thermal cycler (Ebersberg, Germany) using the following conditions: initial denaturation at

$594{ }^{\circ} \mathrm{C}$ for $3 \mathrm{~min}$ followed by 45 cycles of denaturation at $94{ }^{\circ} \mathrm{C}$ for $30 \mathrm{~s}$, annealing at $58{ }^{\circ} \mathrm{C}$

6 for $30 \mathrm{~s}$, extension at $72{ }^{\circ} \mathrm{C}$ for $30 \mathrm{~s}$, and a final extension at $72{ }^{\circ} \mathrm{C}$ for $5 \mathrm{~min}$. Genotyping was

7 carried out on an AB3730xl capillary genotyping system. (Applied Biosystems, Foster City,

8 CA, USA). Allele sizes were scored using the GENEMAPPER software package (v4.1; Applied

9 Biosystems) using LIZ-500 size standards, and were checked by comparison with previously

10 sized control samples. Chromatograms were all inspected visually.

\subsection{Genetic data analysis}

GENEPOP (V3.4; Raymond and Rousset, 1995) was used to test for linkage disequilibrium between nuclear microsatellite loci. To estimate genetic diversity within sites, levels of observed $\left(H_{O}\right)$ and expected $\left(H_{E}\right)$ heterozygosity, levels of allelic richness $\left(A_{R}\right)$ and fixation indices $\left(F_{I S}\right)$ were calculated using the FSTAT software package (V2.9.3.2; Goudet, 2001). Significance of $F_{I S}$ was determined by 10,000 randomisation steps. The overall level of genetic differentiation between sites was estimated using $\Phi_{S T}$, which gives an analogue of $F_{S T}$ (Weir and Cockerham, 1984) calculated within the analysis of molecular variance (AMOVA) framework (Excoffier et al., 1992) using the ARLEQUIN software package (V3.5.1.2; Excoffier and Lischer, 2010). To further identify possible patterns of genetic structure, the software package BAPS (V5; Corander et al., 2003) was used to identify clusters of genetically similar sites using a Bayesian approach. Ten replicates were run for all possible values of the maximum number of clusters $(K)$ up to $K=14$, the number of sites sampled, with a burn-in period of 10,000 iterations followed by 100,000 iterations. An AMOVA was also carried out 
1 based on the groups delineated by the BAPS analysis (see Results), and pairwise $\Phi_{S T}$ values

2 between sites were also estimated.

A test for isolation-by-distance (IBD; Rousset 1997) was carried out to test the null

4 hypothesis of a stepping-stone model of gene flow between sites. The ISOLDE test

5 implemented in the GENEPOP software package was used to assess the relationship between

6 genetic distance, measured as $F_{\mathrm{ST}} /\left(1-F_{\mathrm{ST}}\right)$, and geographical distance between pairs of sites,

7 measured as the shortest distance across water. 1,000 permutations were used for the Mantel

8 test.

9 To test the power of the six microsatellites used in the study to detect low levels of 10 population genetic differentiation, simulations were carried out using the POWSIM software 11 package (V4.0; Ryman and Palm, 2006). Simulations were carried out for an effective population size of $\mathrm{N}_{\mathrm{e}}=1,000$ to yield $F_{\mathrm{ST}}$ values of $0.0005-0.0050$. In all cases, 1,000 replicates were run and the power of the analysis was indicated by the proportion of tests that

14 were significant at $P<0.05$ using the observed allele frequencies for the six microsatellite 15 loci (for $F_{\mathrm{ST}}=0$ this corresponds to the Type $\mathrm{I}[\alpha]$ error).

\subsection{Hydrodynamic and particle tracking modelling}

Dispersal of S. latissima spores was numerically predicted using a particle tracking module coupled to the Irish Sea Hydrodynamic Model (Elsäßer et al., 2010) using MIKE21 modelling software (DHI Water and Environment software package: www.dhisoftware.com).

21 To determine the current field, the Irish Sea Model uses a finite volume method by solving a depth averaged shallow water approximation. While fertile $S$. latissima material can be found between April and November (K. Mooney, Personal Observation), current flow is tidally driven, which is predictable and varies little throughout the year, therefore the model 
1 was run for the month of September as a representative period incorporating two neaps and 2 two spring tides.

3 Two significant temporal factors that will affect the distance that spores travel are tidal state (e.g. flood, ebb or slack tide), which determines how spores are released into the water 5 column, and the length of time that spores are viable. Currently, the optimal tidal state for $S$.

6 latissima spore release is unknown, therefore, a trickle release approach was adopted

7 whereby 200 particles (a proxy for spores) were released every 5 min during the simulation.

8 While there are specific studies on the length of time that spores are viable, these are

9 laboratory based observations with the general consensus that free floating spores are short

10 lived and do not remain viable for more than a few days (Suto, 1950; Kain, 1964; Jones and

11 Babb, 1968; Reed et al., 1992). While propagules of the green alga Ulva are capable of

12 living for up to 8 days (Jones and Babb, 1968), studies of the giant kelp, Macrocystis pyrifera

13 concluded that no zoospores could swim for longer than $120 \mathrm{~h}$ and, in the dark, none longer

14 than $72 \mathrm{~h}$ (Reed et al., 1992). Kain (1964) reported that zoospores of another North Atlantic

15 kelp, Laminaria hyperborea, could not swim longer than $20 \mathrm{~h}$. Based on the information

16 from the studies on the kelps, particles (spores) were given a life span of 5 days in the model

17 before they were terminated. To reach a pseudo stationary pattern, a time series analysis was

18 carried out in the second to last week of the simulation where at each site the number of

19 particles (spores) on the bed per square metre was derived in relation to the number released

20 in the model to this point. This derived the average concentration of particles reaching the

21 bed per square metre.

22 Two important considerations when simulating transport processes in the marine

23 environment are advection and dispersion, where advection is the mean flow $(\bar{u}$ : derived from

24 the hydrodynamic model) that transports particles from one location to another and dispersion

25 is driven by factors such as non-resolved turbulence or eddies. Horizontal and vertical 
1 dispersal movement of the particles were resolved using the Langevin equation. For horizonal

2 movement, the scaled eddy viscosity was used and in the absence of any dispersion

3 information and the recommended constant value in the software of 1.0 was used. For the

4 vertical dispersion, a constant dispersion value of $0.01 \mathrm{~m}^{2} / \mathrm{s}$ was used. As flow velocity

5 changes with depth, a logarithmic velocity profile was calculated based on the bed friction

6 velocity, a parameter calculated in the hydrodynamic model. Each site was simulated

7 separately with particles released $0.5 \mathrm{~m}$ off the substratum to represent an approximate height

8 of S. latissima kelp canopy. 


\section{3. Results}

\subsection{Population genetic analysis}

No significant evidence of consistent linkage disequilibrium (i.e. involving the same loci) was detected between any of the six nuclear microsatellites analysed (4 out of 210 tests).

6 Between six (Zspj39) and 61 (Sac-1H08) alleles were detected per locus, with a total of 133

$7 \quad($ mean $=21.167$ per locus; Table 2$) . F_{I S}$ values by locus ranged from $-0.053($ Zspj39) to

$8 \quad 0.211$ (Sac-1F02). Within sites, levels of allelic richness $\left(A_{\mathrm{R}}\right)$ averaged over loci ranged from

95.546 (S11 - St John's Point) to 7.144 (S4 - Knockinelder), with a mean value of 6.261

10 (Table 1$)$. Levels of observed $\left(H_{\mathrm{O}}\right)$ and expected $\left(H_{\mathrm{E}}\right)$ heterozygosity ranged from 0.554

11 (S12 - Port Erin) to $0.826(\mathrm{~S} 11$ - St John's Point; mean = 0.635), and from $0.616(\mathrm{~S} 6$ -

12 Marlfield) to $0.776(\mathrm{~S} 1-$ Rathlin Island; mean $=0.666)$ respectively. Heterozygote deficits measured as $F_{\text {IS }}$ values were significantly different from zero in seven of the 14 sites studied, ranging from -0.048 (S7 - Walter Shore) to $0.165(\mathrm{~S} 4-$ Knockinelder; mean $=0.074)$.

The AMOVA indicated that $5.89 \%$ of the total genetic variation was partitioned between sites $\left(\Phi_{S T}=0.059 ; P<0.0001\right.$; Table 3$)$. The BAPS analysis identified four genetic clusters: the first contained the Northern Ireland sites north of Belfast Lough (Rathlin Island and Carnlough), the second comprised all the Northern Ireland sites south of Belfast Lough (Bangor, Knockinelder, Tara Bay, Marlfield, Walter Shore, The Dorn, Kircubbin,

20 Audleystown Rocks and St John's Point), the Port Erin site from the Isle of Man formed the 21 third, and the two Scottish sites (Stranraer and Troon) made up the final group (Fig. 2). Multiple independent runs always gave the same outcome. The group-level AMOVA indicated that $7.82 \%$ of the total genetic variation was partitioned between the four groups

24 identified by the BAPS analysis $\left(\Phi_{C T}=0.0782 ; P<0.0001\right.$; Table 3$)$. Finally, a significant pattern of isolation-by-distance was observed across all sites analysed, but not among the 
1 group of sites south of Belfast Lough alone (Fig. 3). Population-pairwise $\Phi_{S T}$ values were

2 significant in all but 13 of the 91 comparisons, which were all between populations from the

3 Southern group, and ranged from 0.009 (S7 - Walter Shore vs. S9 - Kircubbin) to 0.171 (S11

4 - St John's Point vs. S12 - Port Erin; Supplementary Table S1).

5 The simulation studies suggested that the microsatellite data were able to detect $F_{\text {ST }}$ values

6 of as low as $0.003095 \%$ of the time, and in all simulations for $F_{\text {ST }}$ values of 0.0045 and

7 above (Fig. S1).

8

\section{3.2. Hydrodynamic and particle tracking modelling}

10 The most notable feature from the numerical simulations of the particle tracking modelling is

11 the minimal exchange of particles between Northern Ireland, Scotland and Isle of Man

12 populations (Fig. 4). Greatest dispersal was observed at Carnlough (S2) along the north coast

13 of Northern Ireland where tidal flows can reach up to approximately $1 \mathrm{~m} / \mathrm{s}$. The simulations

14 also clearly showed overlap between this site and Rathlin Island (S1). Port Erin (S12), at the

15 tip of the Isle of Man, is also a high flow area with dispersion quite prominent around part of

16 the island, but no overlap between any of the other locations is observed. Given that spores

17 had a lifespan of five days and were released continuously throughout the month of

18 September, localised particle retention was observed at each site, particularly at Bangor (S3).

19 Localised retention coincides with associated low-flow regimes such as at Bangor (S3), the

20 entrance to the Belfast Lough Harbour, and Troon (S14) in Scotland. Conversely, sites inside

21 and adjacent to Strangford Lough (Sites 4-11) appeared to be well-connected, with dispersal

22 in both directions through the entrance to the Lough observed from The Dorn (S8) and St.

23 John's Point (S11).

Page $\mid 12$ 


\section{4. Discussion}

3 These findings reveal a hierarchical structure of genetic differentiation in the kelp Saccharina

4 latissima across the Irish and Inner Seas. At smaller scales (less than a few 10s of $\mathrm{km}$ ), gene

5 flow appears to be fairly extensive, with evidence of connectivity between sites due to local

6 currents. At larger scales, however, factors such as freshwater efflux and open water would

7 appear to represent barriers to gene flow. Together, these patterns suggest that factors other

8 than simple geographical distance and proximity need to be taken into account when planning

9 the siting of kelp farms and sourcing culture broodstock, with the aim of minimizing gene

10 flow to and from natural populations.

11 The overall value for population differentiation observed in the present study $\left(\Phi_{\mathrm{ST}}=\right.$

$120.059)$ was lower than both the mean (0.211) and median (0.130) values reported for 101

13 macroalgal studies by Durrant et al. (2014), and for the subset of these studies that examined

14 kelps $($ mean $=0.148 ;$ median $=0.080 ; n=21)$. While macroalgae typically display isolation-

15 by-distance (IBD), our findings suggest that for S. latissima, this may be more pertinent at

16 larger geographic scales, and they also reflect the results of previous genetic studies on the

17 species, which found greater levels of differentiation at geographical scales over an order of

18 magnitude greater than those examined in the present study. Nielsen et al. (2016) observed a

19 main pairwise $F_{S T}$ of 0.096 between populations from a transition zone across the North and

20 Baltic seas, with some evidence of IBD. It should be noted, though, that this was partly due

21 to differences between marine and brackish populations $\left(\Phi_{S T}=0.127\right)$, whilst lower mean

22 values were observed between pairs of populations classed as either marine $\left(F_{S T}=0.073\right)$ or

23 brackish $\left(F_{S T}=0.040\right)$. Guzinski et al. (2016) observed a mean value of $F_{S T}=0.358$ between

24 European populations spanning several thousand kilometres, but with no clear evidence of

25 IBD, whilst Luttikhuizen et al. (2018) estimated $F_{S T}=0.267$ between natural populations 
1 ranging from Northern Norway to Brittany, a range around an order of magnitude greater

2 than that covered by the present study.

The isolation of Scottish and Isle of Man populations from those in Northern Ireland and

4 from each other was expected, given the current flow velocity and direction and large

5 distances that spores would have to cross to breed similar populations, although the

6 separation of the Northern Irish populations into separate northern and southern groups was

7 unexpected. The Scottish populations are ca. $65 \mathrm{~km}$ apart, with Stranraer (S13) experiencing

8 current flows up to $0.4 \mathrm{~m} / \mathrm{s}$ at the south of Loch Ryan while Troon (S14) is on the edge of the

9 Firth of Clyde experiencing flows $<0.1 \mathrm{~m} / \mathrm{s}$. Despite the large geographical distance and low

10 flow velocities, these sites belong to the same genetic cluster. By contrast, the Northern Irish

11 sites cover a total distance of $c a .140 \mathrm{~km}$ from Rathlin Island (S1) in the north to St. John's

12 Point (S11) at the southernmost site. This coastline is a combination of wave and current

13 conditions with low flow velocities $<0.1 \mathrm{~m} / \mathrm{s}$ in the loughs (Strangford Lough and Belfast

14 Lough), and wave sheltered harbour (where the Rathlin samples were taken). Microsatellite

15 analysis showed that these populations form two distinct genetic clusters. The northern pair

16 which form the first cluster, Rathlin Island (S1) and Carnlough (S2), are ca. $40 \mathrm{~km}$ apart,

17 while the southern group included sites along the outside of the Ards peninsula (Bangor (S3)

18 and St John's Point (S11), ca. $65 \mathrm{~km}$ apart), as well as those from the predominantly current

19 landlocked Strangford Lough (Kregting and Elsäßer 2014). While geographical distances

20 between sites within these two clusters are similar to that between the Scottish populations, it

21 should be noted that the sites within Strangford Lough are genetically similar to those outside

22 the Lough, despite the marked habitat discontinuities. This shows that there are factors other

23 than geographical distance or habitat discontinuity affecting genetic differentiation patterns,

24 which could reflect the proportion (64\%) of significant pairwise $\Phi_{S T}$ values between these

25 sites and the small but significant level of differentiation between populations within the four 
1 clusters (1.55\% of the total genetic variation), although there were no apparent geographical

2 patterns in these values. Similar genetic differentiation was found in eastern Maine, USA,

3 where two populations which were $\sim 50 \mathrm{~km}$ apart were genetically different while nearby

4 populations up to $90 \mathrm{~km}$ apart had genetic mixing (Breton et al., 2018).

Hydrodynamic modelling shows patterns of spore dispersal that are generally consistent

6 with the genetic patterns seen in the Northern Irish sites sampled. Simulated spore release

7 from the Rathlin Island (S1) and Carnlough (S2) sites show that there is mixing between both

8 sites. Simulated releases from The Dorn (S8) (within Strangford Lough) and St. John's Point

9 (S11) (outside the Lough) show mixing of spores and explain how the habitat discontinuity

10 within the southern group can be overcome by hydrodynamic influence. Populations of $S$.

11 latissima in and around Strangford Lough exhibit a higher degree of connectivity than populations of Laminaria digitata from the same area (Brennan et al. 2014). The lack of significant IBD in the southern populations in the present study is reflected in the low levels of $F_{I S}$, suggesting substantial gene flow and little inbreeding, and is in contrast to significant levels of both IBD and inbreeding observed in L. digitata in the previous study. Interestingly, at the north of the southern group, spores released from Bangor (S3) apparently have a very narrow dispersal while those from Carnlough (S2) in the northern group, although they have a very wide dispersal, do not appear to travel far enough to reach the Bangor sites. These sites are situated either side of Belfast Lough, which has a large freshwater plume that enters the Irish Sea that results in fluctuating salinity (Service et al., 1996). It is most likely this change in salinity gradient represents a barrier to spore dispersal and survival.

With the projected increase in coastal kelp farming, it is important to be aware of the potential for interaction between farmed and natural populations, especially given the capacities for dispersal indicated in the present study. Although lack of suitable (i.e. rocky) substrate has been proposed to be a major dispersal barrier for several kelps (Alberto et al., 
1 2010; Couceiro et al., 2013; Robuchon et al., 2014), the establishment of longline systems

2 and similar growth structures may provide a way to overcome both substrate and isolation-

3 by-distance barriers, by acting as "stepping stones" for dispersal of fertile material and

4 gametes. However, kelp gamete dispersal does not necessarily lead to successful

5 reproduction and colonisation. Even if spores are dispersed, there is a "Goldilocks-like"

6 cocktail of criteria to be met for success, including a sufficient quantity of male and female

7 gametes for fertilisation to occur, suitable substrate for gametophytes and juvenile

8 sporophytes to settle on, low enough grazing pressure, suitable photosynthetically active

9 radiation (PAR) and temperature, sufficient nutrient and salinity gradients, and the right

10 amount of current and wave exposure (Gaylord et al., 2002; Schiel and Foster, 2006;

11 Andersen et al., 2013, Kregting et al., 2015; van der Molen et al., 2018). For offshore sites, it

12 is highly unlikely that such a combination of factors will be met although the potential is

13 greater in nearshore sites.

14 The direct transplant of seaweed cultures from one region to another could overcome

15 natural obstacles to gene flow and dispersal such as hydrodynamic or salinity barriers,

16 allowing establishment of genetically distinct populations in a new region. Translocation of seaweed species into non-native areas has led to establishment of invasive species, such as the spread of Undaria pinnitifida from cultivated sites in Brittany, France to Portugal, the Netherlands, Belgium, Ireland and the UK (Kraan, 2016). Consequently, new marine policy guidance from the Scottish Government recommends that only species local to the production area should be farmed, to reduce the risk of establishment of invasive species in the future

22 (Marine Scotland, 2017). In addition, poleward shifts of several kelp species are evident, for example species with a warmer water affinity, such as Laminaria ochroleuca, are expanding

24 their ranges while colder water species, such as Alaria esculenta, L. hyperborea and $L$.

25 digtata are predicted to contract (Smale et al., 2015; Brodie et al. 2014; Franco et al. 2018). 
1 The presence of kelp farms may exacerbate these species range shifts, by extending the

2 typical dispersal potential of farmed kelp spores via cultivation sites acting as stepping stones

3 for settlement of wild kelp and fertile farmed adults. Uncertainties associated with these

4 anthropogenic translocations of genetically differentiated material means that great care will

5 need to be taken to minimise potential modifications of natural dispersal processes and

6 resulting patterns of genetic diversity following the establishment of kelp farms. 


\section{Acknowledgements}

2 The authors are grateful to Matt Dring for comments on the manuscript. Aspects of this work

3 were funded through the INTERREG IVB North West Strategic Initiative EnAlgae, the

4 InnovateUK SeaGas project, and by a Queen's University Belfast Fellowship to LK. 


\section{References}

3 Alberto, F., Raimondi, P. T., Reed, D. C., Coelho, N. C., Lebois, R., Whitmer, A., Serrão, E.

A. 2010. Habitat continuity and geographic distance predict population genetic differentiation in kelp. Ecology 91, 49-56.

6 Andersen G. S., Pedersen, M. F., Nielsen, S. L. 2013. Temperature acclimation and heat tolerance of photosynthesis in Norwegian Saccharina latissima (Laminariales, Phaeophyceae). J. Phycol. 49, 689-700.

Bartsch, I., Wiencke, C., Bischof, K., Buchholz, C. M., Buck, B. H., Eggert, A., Feuerpfeil, P., Hanelt, D., Jacobsen, S., Karez, R., Karsten, U., Molis, M., Roleda, M. Y., Schubert, H., Schumann, R., Valentin, K., Weinberger, F., Wiese, J. 2008. The genus Laminaria sensu lato: recent insights and developments. Eur. J. Phycol. 43, 1-86.

Billot, C., Engel, C. R., Rousvoal, S., Kloareg, B., Valero, M. 2003. Current patterns, habitat discontinuities and population genetic structure: the case of the kelp Laminaria digitata in the English Channel. Mar. Ecol. Progress Ser. 215, 111-121.

Bolton, J. J. 2010. The biogeography of kelps (Laminariales, Phaeophyceae): a global analysis with new insights from recent advances in molecular phylogenetics. Helgoland Mar. Res. 64, 263-279.

Brennan, G., Kregting, L., Beatty, G. E., Cole, C., Elsäßer, Savidge, G., Provan, J. 2014. Understanding macroalgal dispersal in a complex hydrodynamic environment: a combined population genetic and physical modelling approach. J. R. Soc. Interface 11, 2014097.

Breton, T. S., Nettleton, J. C., O’Connell, B, Bertocci, M. 2018. Fine-scale population genetic structure of sugar kelp, Saccharina latissima (Laminariales, Phaeophyceae), in eastern Maine, USA. Phycologia 57, 32-40. 
1 Brodie, J., Williamson, C. J., Smale, D. A., Kamenos, N. A., Mieszkowska, N., Santos, R.,

2 Cunliffe, M., Steinke, M., Yesson, C., Anderson, K. M., Asnaghi, V., Brownlee, C.,

3 Burdett, H. L., Burrows, M. T., Collins, S., Donohue, P. J. C., Harvey, B., Foggo, A.,

4 Noisette, F., Nunes, J., Ragazzola, F., Raven, J. A., Schmidt, D. N., Suggett, D.,

5 Teichberg, M., Hall-Spencer, J. M. 2014. The future of the northeast Atlantic benthic

6 flora in a high $\mathrm{CO}_{2}$ world. Ecol. Evol. 4, 2787-2798.

7 Buschmann, A. H., Camus, C., Infante, J., Neori, A., Israel, A., Hernández-González, M. C.,

8 Pereda, S. V., Gomez-Pinchetti, J. L., Golberg, A., Tadmor-Shalev, N., Critchley, A. T.

9 2017. Seaweed production: overview of the global state of exploitation, farming and

10 emerging research activity. Eur. J. Phycol. 52, 391-406.

11 Coleman, M. A., Gillanders, B. M., Connell, S. D. 2009. Dispersal and gene flow in the

12 habitat-forming kelp, Ecklonia radiata: relative degrees of isolation across an east-west

13 coastline. Mar. Freshw. Res. 60, 802-809.

14 Corander, J., Waldmann, P., Sillanpää, M. J. 2003. Bayesian analysis of genetic

15 differentiation between populations. Genetics 163, 367-374.

16 Couceiro, L., Robuchon, R., Destombe C., Valero, M. 2013. Management and conservation

17 of the kelp species Laminaria digitata: using genetic tools to explore the potential

18 exporting role of the MPA “Parc naturel marin d'Iroise”. Aquat. Living Resources 26,

19 197-205.

20 Dayton, P. K. 1985. Ecology of kelp communities. Annual Rev. Ecol. Syst. 16, 215-245.

21 Doyle, J. J., Doyle, J. L. 1987. A rapid DNA isolation procedure for small quantities of fresh

22 leaf tissue. Phytochem. Bull. 19, 1-15.

23 Durrant, H. M. S., Burridge, C. P., Kelaher, B. P., Barrett, N. S., Edgar, G. J., Coleman, M.

24 A. 2014. Implications of macroalgal isolation by distance for networks of marine

25 protected areas. Conserv. Biol. 28, 438-445.

Page | 20 
1 Edwards, M. D., Dring, M. J. 2011. Open-sea cultivation trial of the red alga, Palmaria

2 palmata from seeded tetraspores in Strangford Lough, Northern Ireland. Aquaculture 317, $3 \quad 203-209$.

4 Elsäßer, B., Bell, A. K., Shannon, N., Robinson, C. 2010. Storm surge hind- and forecasting 5 using MIKE21FM - simulation of surges around the Irish coast. In: Proceedings of the

6 International MIKE by DHI Conference - Modelling in a World of Change, Copenhagen,

$7 \quad$ Denmark.

8 Excoffier, L., Smouse, P. E., Quattro, J. M. 1992. Analysis of molecular variance inferred from metric distances among DNA haplotypes - application to human mitochondrial DNA

11 Excoffier, L., Lischer, H. E. L. 2010. Arlequin suite ver 3.5: a new series of programs to perform population genetics analyses under Linux and Windows. Mol. Ecol. Res. 10,

14 FAO (2016). The State of World Fisheries and Aquaculture 2016. (SOFIA).

15 Franco, J. N., Tuya, F., Bertocci, I., Rodriguez, L., Martínez, B., Sousa-Pinto, I., Arenas, F. 16 2018. The "golden kelp" Laminaria ochroleuca under global change: Integrating multiple 17 eco-physiological responses with species distribution models. J. Ecol. 106, 47-58.

18 Fredriksen, S., Sjøtun, K., Lein, T. E., Rueness, J. 1995. Spore dispersal in Laminaria hyperborea (Laminariales, Phaeophyceae). Sarsia 80, 47-53

20 Gaylord, B., Reed, D. C., Raimondi, P. T., Washburn, L., McLean, S. R. 2002. A physically 21 based model of macroalgal spore dispersal in the wave and current-dominated nearshore. 22 Ecology 83, 1239-1251.

23 Goudet, J. 2001. FSTAT, version 2.9.3, A program to estimate and test gene diversities and 24 fixation indices. http://www2.unil.ch/popgen/softwares/fstat.htm. 
1 Guzinski, J., Mauger, S., Cock, J. M., Valero, M. 2016. Characterization of newly developed

2 expressed sequence tag-derived microsatellite markers revealed low genetic diversity

3 within and low connectivity between European Saccharina latissima populations. J. Appl.

$4 \quad$ Phycol. 28, 3057-3050.

5 Jones, W., Babb, S. 1968. The motile period of swarmers of Enteromorpha intestinalis (L.)

$6 \quad$ link. British Phycol. Bull. 3, 525-528.

7 Kain, J. 1964. Aspects of the biology of Laminaria hyperborea III. Survival and growth of gametophytes. J. Mar. Biol. Assoc. UK, 44, 415-433.

9 Kerrison, P. D., Stanley, M. S., Edwards, M. D., Black, K. D., Hughes, A. D. 2015. The 10 cultivation of European kelp for bioenergy: Site and species selection. Biomass and 11 Bioenergy 80, 229-242.

Kijas, J. M., Fowler, J. C., Garbett, C. A., Thomas, M. R. 1994. Enrichment of microsatellites from the citrus genome using biotinylated oligonucleotide sequences bound to streptavidin-coated magnetic particles. BioTechniques 16, 656-660.

Kraan, S. 2016. Undaria marching on; late arrival in the Republic of Ireland. J. Appl. Phycol. $29,1-8$

Kregting, L. T., \& Elsäßer, B. 2014. A hydrodynamic modelling framework for Strangford Lough part 1: tidal model. J. Mar. Sci. Eng. 2, 46-65.

Kregting, L. T., Hepburn, C. D., Savidge, G. 2015. Seasonal differences in the effects of oscillatory and uni-directional flow on the growth and nitrate-uptake rates of juvenile Laminaria digitata (Phaeophyceae). J. Phycol. 51, 1116-1126. 
1 Lehahn, Y., Ingle, K. N., Golberg, A. 2016. Global potential of offshore and shallow waters macroalgal biorefineries to provide food, chemicals and energy: feasibility and sustainability. Algal Res. 17, 150-160.

Luttikhuizen, P. C., van den Heuvel, F. H. M., Rebours, C., Witte, H. J., van Bleijswijk, J. D. L., Timmermans, K. 2018. Strong population structure but no equilibrium yet: Genetic connectivity and phylogeography in the kelp Saccharina latissima (Laminariales, Phaeophyta). Ecol. Evol. 8, 4265-4277

Marine Scotland, 2017. Seaweed cultivation policy statement. ISBN: 9781786528643

Nielsen, M. M., Paulino, C., Neiva, J., Krause-Jense, D., Bruhn, A., Serrao, E. A. 2016. Genetic diversity of Saccharina latissima (Phaeophyceae) along a salinity gradient in the North Sea-Baltic Sea transition zone. J. Phycol. 52, 523-531.

Norton, T. A. 1992. Dispersal by macroalgae. British Phycol. J. 27, 293-301.

Parke, M. 1948. Studies on British Laminariaceae. I. Growth in Laminaria saccharina (L.) Lamour. J. Mar. Biol. Assoc. UK, 27, 651-709.

Radulovich, R., Neori, A., Valderrama, D., Reddy, C. R. K., Cronin, H., Forster, J. 2015. Farming of seaweeds. In B. Tiwari \& D. Troy (Eds.), Seaweed Sustainability - Food and

Raymond, M., Rousset, F. 1995. GENEPOP (version 1.2): population genetic software for exact tests and ecumenicism. J. Hered. 86, 248-249.

Reed, D. C., Amsler, C. D., Ebeling, A. W. 1992. Dispersal in kelps: factors affecting spore swimming and competency. Ecology 73, 1577-1585.

Robuchon, M., Le Gall, L., Mauger, S., Valero, M. 2014. Contrasting genetic diversity Ecol. 23, 2669-2685. 
1 Rousset, F. 1997. Genetic differentiation and estimation of gene flow from F-statistics under isolation by distance. Genetics $145,1219-1228$.

3 Ryman N., Palm S. 2006. POWSIM: a computer program for assessing statistical power when testing for genetic differentiation. Mol. Ecol. Notes 6, 600-602.

Schiel, D. R., Foster, M. S. 2006. The population biology of large brown seaweeds:

6 Ecological consequences of multiphase life histories in dynamic coastal environments.

$7 \quad$ Annual Rev. Ecol. Evol. Syst. 37, 343-372.

Schlarb-Ridley, B. Parker, B. 2013. A UK Roadmap for Algal Technologies. Natural Environment Research Council. UK.

Service, M., Durrant, A. E., Mills, J. A., Taylor, J. E., Faughey, D. 1996. The trophic status of two Northern Ireland sea loughs. J. Coastal Conserv. 2, 159-168.

Smale, D. A., Burrows, M. T., Moore, P., O’Connor, N., Hawkins, S. J. 2013. Threats and knowledge gaps for ecosystem services provided by kelp forests: a northeast Atlantic perspective. Ecol. Evol. 3, 4016-4038.

Smale, D. A., Wernberg, T., Yunnie, A. L. E., Vance, T. 2015. The rise of Laminaria ochroleuca in the Western English Channel (UK) and comparisons with its competitor and assemblage dominant Laminaria hyperborea. Mar. Ecol. 36, 1033-1044.

Stévant, P., Rebours, C., Chapman, A. 2017. Seaweed aquaculture in Norway: recent industrial developments and future perspectives. Aquaculture International 25, 13731390.

Stevens, C. L., Taylor, D. I., Delaux, S., Smith, M. J., \& Schiel, D. R. 2008. Characterisation of wave-influenced macroalgal propagule settlement. J. Mar. Syst. 74, 96-107. Japanese Soc. Sci. Fisheries, 15, 671-673. 
1 Van der Molen, J., Ruardij, P., Mooney, K., Kerrison, P., O’Connor, N., Gorman, E.,

2 Timmermans, K., Wright, S., Kelly, M., Hughes, A. D., Capuzzo, E. 2018. Modelling

3 potential production of macroalgae farms in UK and Dutch coastal waters. Biogeosciences

$4 \quad 15,1123-1147$.

5 Wei, N., Quarterman, J., Jin, Y. S. 2013. Marine macroalgae: an untapped resource for

6 producing fuels and chemicals. Trends Biotech. 31, 70-77.

7 Weir, B. S., Cockerham, C. C. 1984. Estimating F-statistics for the analysis of population

$8 \quad$ structure. Evolution 38, 1358-1370.

9 Wood, D., Capuzzo, E., Kirby, D., Mooney-McAuley, K., Kerrison, P. 2017. UK macroalgae 10 aquaculture: What are the key environmental and licensing considerations? Mar. Policy, $11 \quad 83,29-39$.

12 Zhang, L., Peng, J., Li, X., Liu, Y., Cui, C., Wu, H., Tian, P., Li, Y. (2014). Development of 1327 trinucleotide microsatellite markers for Saccharina japonica using next generation 14 sequencing technology. Conserv. Genet. Res. 6, 341-344. 
Table 1

Details of populations studied. $N$ - number of individuals analysed; $A_{\mathrm{R}}-$ allelic richness; $H_{\mathrm{O}}-$ observed heterozygosity; $H_{\mathrm{E}}-$ expected heterozygosity; $F_{\text {IS }}-$ inbreeding coefficient $(* P<0.05, * * P<0.01$, NS Non-significant).

\begin{tabular}{|c|c|c|c|c|c|c|c|c|}
\hline Site & Name & Lat $(\mathrm{N})$ & Long (W) & $N$ & $A_{R}$ & $H_{O}$ & $H_{E}$ & $F_{I S}$ \\
\hline 1 & Rathlin Island & 55.293 & 6.194 & 29 & 6.038 & 0.781 & 0.776 & $-0.006^{\mathrm{NS}}$ \\
\hline 2 & Carnlough & 55.004 & 5.983 & 30 & 6.793 & 0.595 & 0.674 & $0.118 * *$ \\
\hline 3 & Bangor & 54.666 & 5.665 & 29 & 6.193 & 0.595 & 0.695 & $0.145^{* *}$ \\
\hline 4 & Knockinelder & 54.383 & 5.482 & 28 & 7.144 & 0.594 & 0.709 & $0.165 * * *$ \\
\hline 5 & Tara Bay & 54.350 & 5.490 & 29 & 6.250 & 0.638 & 0.673 & $0.052^{\mathrm{NS}}$ \\
\hline 6 & Marlfield & 54.402 & 5.580 & 30 & 6.340 & 0.583 & 0.616 & $0.054^{\mathrm{NS}}$ \\
\hline 7 & Walter Shore & 54.380 & 5.558 & 31 & 5.790 & 0.660 & 0.631 & $-0.048^{\mathrm{NS}}$ \\
\hline 8 & The Dorn & 54.440 & 5.548 & 30 & 6.423 & 0.618 & 0.640 & $0.035^{\mathrm{NS}}$ \\
\hline 9 & Kircubbin & 54.485 & 5.538 & 30 & 6.297 & 0.620 & 0.650 & $0.048^{\mathrm{NS}}$ \\
\hline 10 & Audleystown Rocks & 54.380 & 5.572 & 30 & 5.793 & 0.618 & 0.646 & $0.044^{\mathrm{NS}}$ \\
\hline 11 & St John's Point & 54.227 & 5.660 & 23 & 5.546 & 0.826 & 0.644 & $0.109 *$ \\
\hline 12 & Port Erin & 54.089 & 4.763 & 17 & 6.201 & 0.554 & 0.642 & $0.141 * *$ \\
\hline 13 & Stranraer & 55.008 & 5.048 & 27 & 6.488 & 0.646 & 0.704 & $0.084 *$ \\
\hline 14 & Troon & 55.541 & 4.670 & 14 & 6.356 & 0.565 & 0.625 & $0.099 *$ \\
\hline
\end{tabular}

Page $\mid 26$ 
Table 2

Details of microsatellite markers used in this study. Zspj39 was originally developed for Saccharina japonica (Zhang et al. 2014). * $F_{I S}$ value for locus Sac-1F02 significant $(P=0.04)$.

\begin{tabular}{|c|c|c|c|c|c|}
\hline Locus & Repeat & Primers $\left(5^{\prime}-3^{\prime}\right)$ & Alleles & $F_{I S}$ & $\begin{array}{c}\text { Size range } \\
\text { (bp) }\end{array}$ \\
\hline \multirow[t]{2}{*}{ Sac-1B02 } & $(\mathrm{TTG})_{20}$ & AGCCCTCTCTCAAGTCGTGCGT & 28 & 0.029 & $190-280$ \\
\hline & & TCTCCGCACAAGCCGTTATCCC & & & \\
\hline \multirow[t]{2}{*}{ Sac-1B05 } & $(\mathrm{TGC})_{8} \ldots(\mathrm{TGC})_{5} \ldots(\mathrm{TGC})_{7}$ & TGCGGTAGCGGTAGCACTTTGA & 11 & -0.053 & $233-278$ \\
\hline & & GCGTGTACCCCGAAATCGGACA & & & \\
\hline \multirow[t]{2}{*}{ Sac-1F02 } & $(\mathrm{GCT})_{7}(\mathrm{GCC})_{2}(\mathrm{GCT})_{3} \mathrm{GCC}(\mathrm{GCT})_{5}(\mathrm{GAT})_{4}$ & TACGAGGAGGGCGTGCTGGTTT & 10 & $0.211^{*}$ & $177-273$ \\
\hline & & GTGCTGTATTTACGCGATCTCGTGGG & & & \\
\hline \multirow[t]{2}{*}{ Sac-1H08 } & $(\mathrm{TTGT})_{16}$ & TAATGTCTCTTTTATGCATGCC & 61 & 0.075 & $302-614$ \\
\hline & & GGTGTGGCTGTCGGACCC & & & \\
\hline \multirow[t]{2}{*}{ Sac-2C10 } & $(\mathrm{CAG})_{10}$ & ATCAAACACAACTGTTGCTGGAATGGA & 17 & 0.015 & $334-382$ \\
\hline & & GCACTGCCTTGGAAGAGCGGAA & & & \\
\hline \multirow[t]{2}{*}{ Zspj39 } & $(\mathrm{GGA})_{12}$ & CTCGGTTCAAAGTTCCGCAAG & 6 & 0.042 & $243-264$ \\
\hline & & CATCCGCAATTTCTTCCACGG & & & \\
\hline
\end{tabular}


Table 3

Analysis of Molecular Variance (AMOVA). The groups in the lower Table correspond to the four genetic clusters delineated by the BAPS analysis.

\begin{tabular}{llllll}
\hline Source of variation & $\mathrm{df}$ & Sum of squares & Variance components & $\%$ variation & $P$ \\
\hline Among populations & 13 & 100.142 & 0.111 & 5.89 & $P<0.001$ \\
Within populations & 736 & 1305.242 & 1.773 & 94.11 & \\
\hline
\end{tabular}

\begin{tabular}{llllll}
\hline Source of variation & $\mathrm{df}$ & Sum of squares & Variance components & $\%$ variation & $P$ \\
\hline Among groups & 3 & 65.583 & 0.153 & 7.82 & $P<0.001$ \\
Among populations within groups & 10 & 34.559 & 0.030 & 1.55 & $P<0.001$ \\
Within populations & 736 & 1305.242 & 1.773 & 90.63 & $P<0.001$ \\
\hline
\end{tabular}

Page $\mid 28$ 


\section{Figure Legends}

Fig. 1. Map of sampling sites - inset shows detail of populations in and around Strangford Lough. Numbers refer to Table 1.

Fig. 2. Results of the BAPS analysis. Different colours represent assignment to one of four different genetic clusters. Numbers refer to populations in Table 1 and Figure 1.

Fig. 3. Results of the isolation-by-distance analysis: (a) all populations; (b) populations from the southern (i.e. yellow) BAPS cluster.

Fig. 4. Particle distribution from eight representative release sites $(1,2,3,8,11,12,13$ and 14; Table 1 and Figure 1). Release of particles is constant simulating trickle spawning; time step 5 min, 200 particles per time step (see Materials and Methods for details).

Fig. S1. Results of the POWSIM analysis. The Y-axis represents the power of the markers to successfully recover the value of $F_{\mathrm{ST}}$ indicated on the $\mathrm{X}$-axis, expressed as the proportion of 1000 simulations (see text for details). For $F_{S T}=0$, this is the Type I $(\alpha)$ value. 


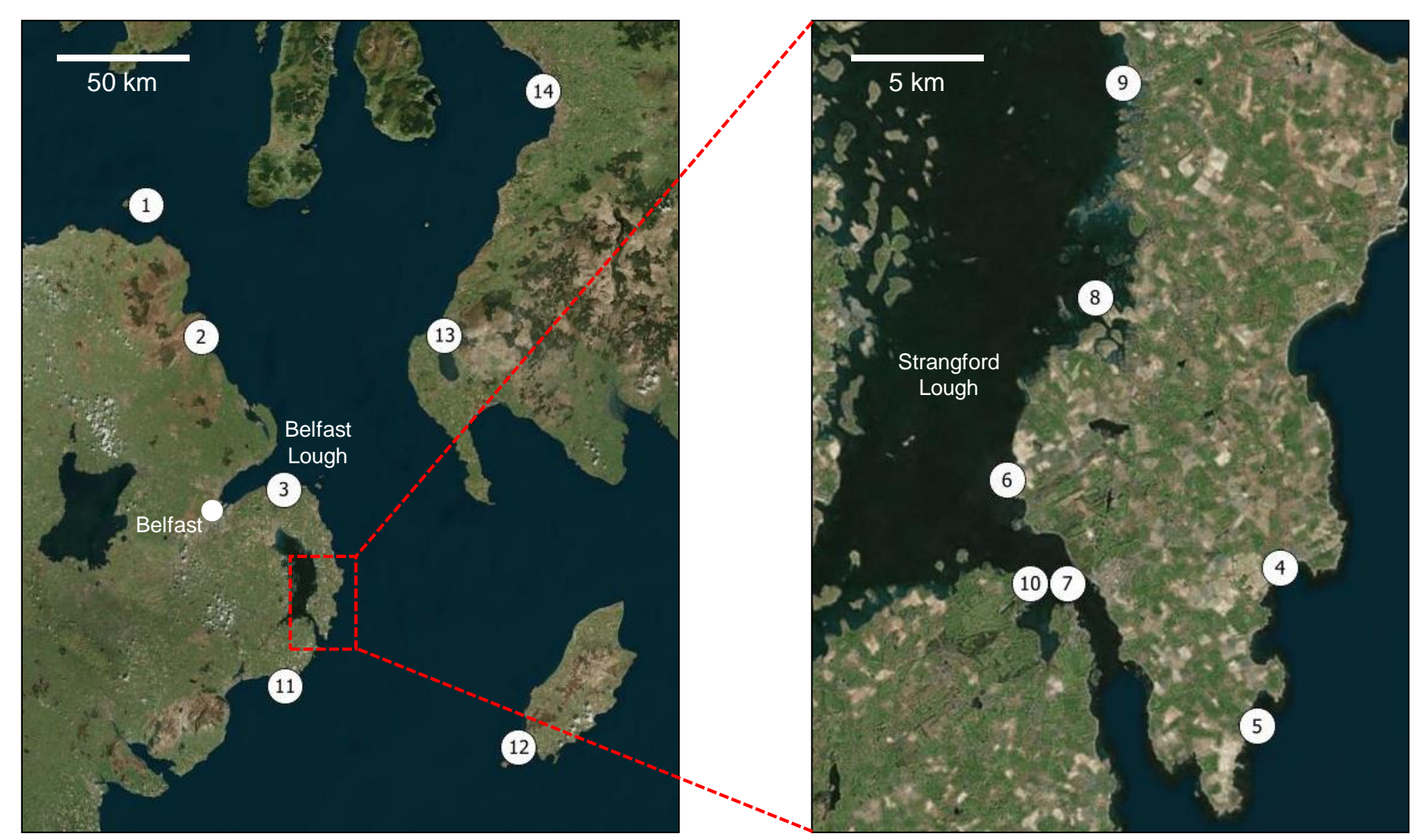

Page | 30 


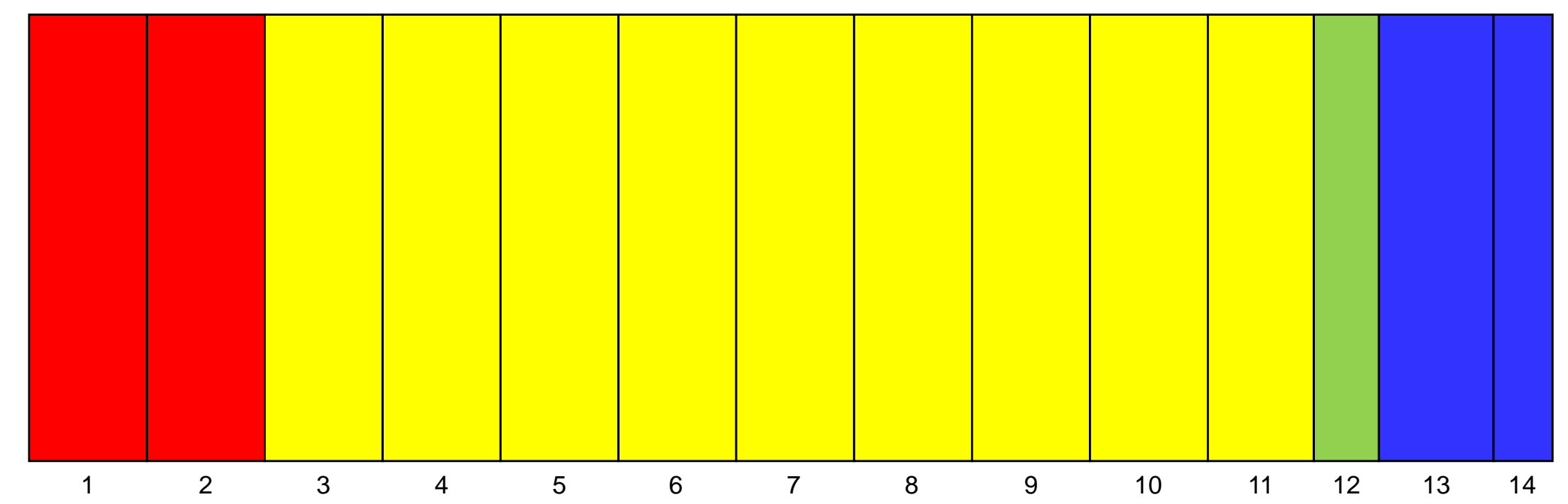

Page | 31 

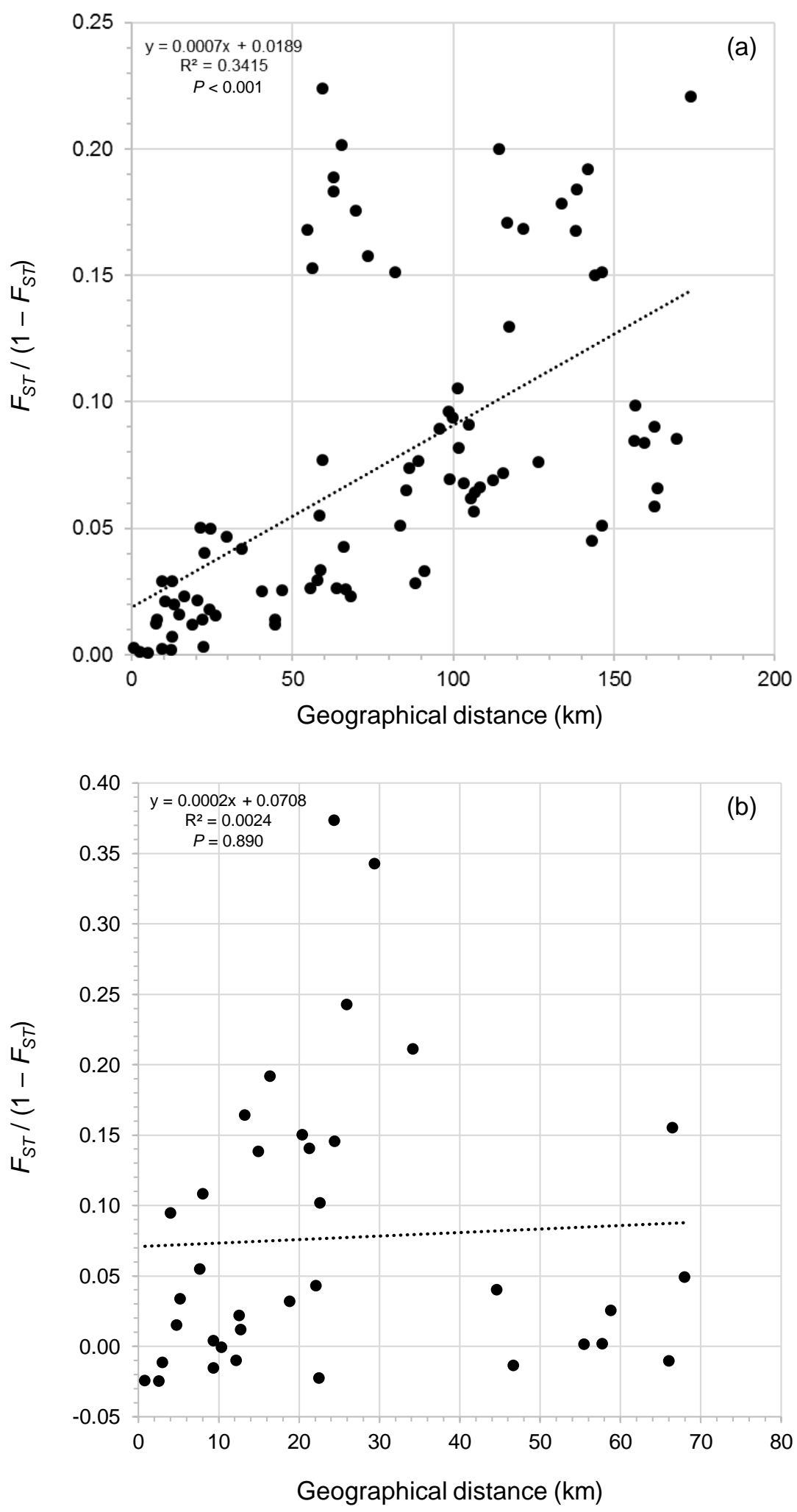

Page | 32 


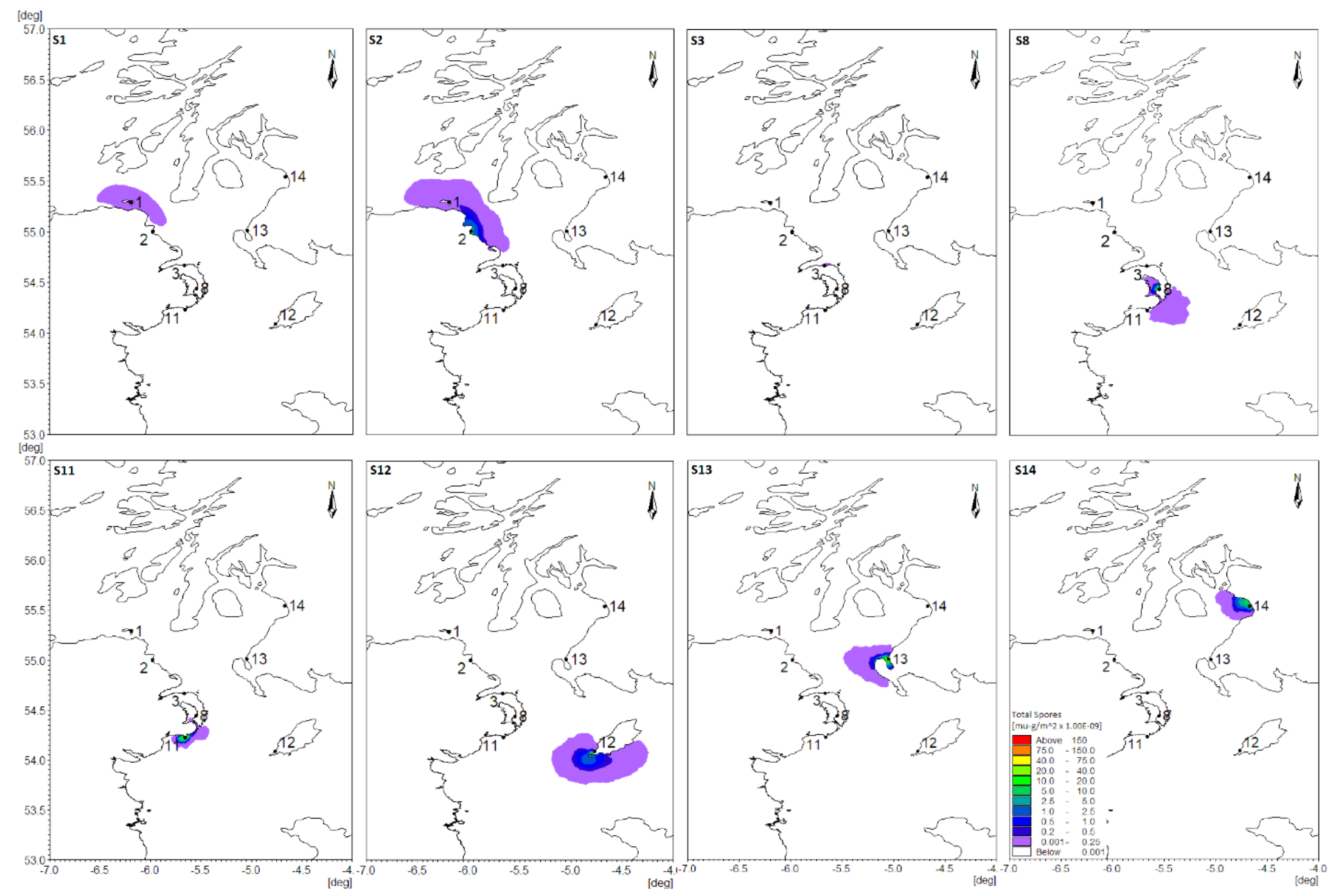

Page | 33 
Table S1 Population-pairwise $\Phi_{S T}$ values. Site numbers refer to those in Table 1. Values not significantly different from zero are given in italics.

\begin{tabular}{|c|c|c|c|c|c|c|c|c|c|c|c|c|c|c|}
\hline Site & 1 & 2 & 3 & 4 & 5 & 6 & 7 & 8 & 9 & 10 & 11 & 12 & 13 & 14 \\
\hline 1 & - & & & & & & & & & & & & & \\
\hline 2 & 0.025 & - & & & & & & & & & & & & \\
\hline 3 & 0.061 & 0.010 & - & & & & & & & & & & & \\
\hline 4 & 0.114 & 0.048 & 0.006 & - & & & & & & & & & & \\
\hline 5 & 0.149 & 0.069 & 0.028 & -0.009 & - & & & & & & & & & \\
\hline 6 & 0.158 & 0.086 & 0.036 & 0.019 & 0.029 & - & & & & & & & & \\
\hline 7 & 0.154 & 0.083 & 0.027 & 0.018 & 0.027 & -0.001 & - & & & & & & & \\
\hline 8 & 0.132 & 0.058 & 0.027 & 0.014 & 0.021 & 0.003 & 0.015 & - & & & & & & \\
\hline 9 & 0.133 & 0.063 & 0.025 & 0.014 & 0.014 & 0.005 & 0.009 & 0.000 & - & & & & & \\
\hline 10 & 0.142 & 0.083 & 0.018 & 0.015 & 0.007 & -0.008 & -0.003 & 0.005 & -0.004 & - & & & & \\
\hline 11 & 0.157 & 0.076 & 0.023 & 0.002 & -0.008 & 0.035 & 0.040 & 0.035 & 0.031 & 0.040 & - & & & \\
\hline 12 & 0.088 & 0.075 & 0.073 & 0.123 & 0.141 & 0.169 & 0.154 & 0.151 & 0.137 & 0.152 & 0.171 & - & & \\
\hline 13 & 0.135 & 0.075 & 0.054 & 0.028 & 0.030 & 0.067 & 0.079 & 0.063 & 0.069 & 0.062 & 0.047 & 0.147 & - & \\
\hline 14 & 0.167 & 0.094 & 0.061 & 0.045 & 0.038 & 0.070 & 0.086 & 0.058 & 0.076 & 0.079 & 0.060 & 0.174 & 0.024 & - \\
\hline
\end{tabular}




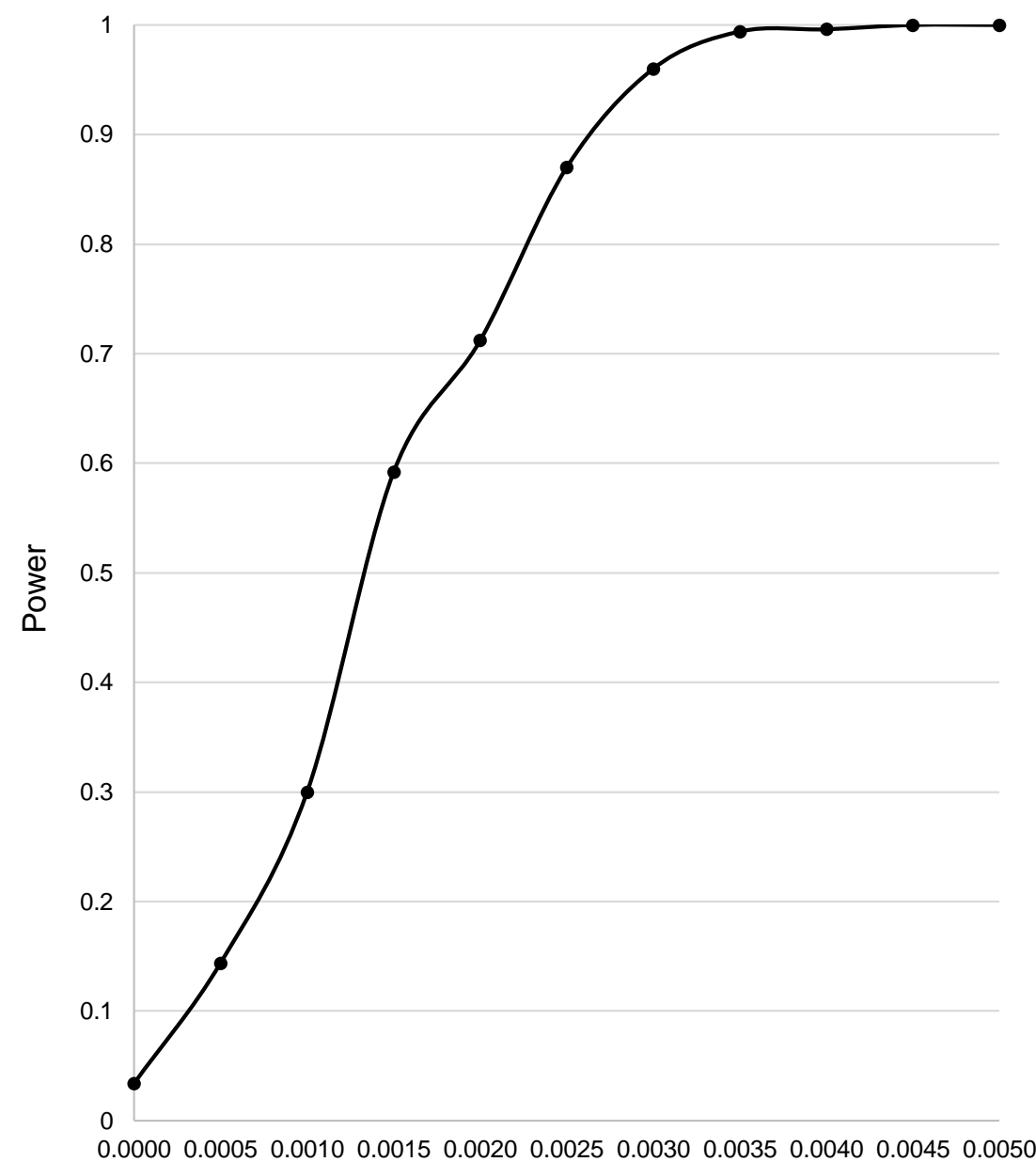

$F_{\mathrm{ST}}$ 